\title{
Peningkatan Motivasi dan Hasil Belajar Melalui Metode Buzz Group
}

\author{
Hardyanti Bahning \\ Prodi Pendidikan Agama Islam, IAIN Palopo \\ Email: yantibahning@gmail.com
}

\begin{abstract}
This research supported by the lack of motivation and learning outcomes islamic education students educated at. vocational schoolThe purpose of this research to know the learning methods he continued to buzz can increase motivation and learning outcomes in learning. islamic educationThis study research the act of class (class room action research conducted). cycle as much asThe subject is the muslim students xi route tourism state 1 integrated luwu ponrang 24. as the southData collection techniques used is, observation the survey and by using an instrument shaped double. about choiceData analyzed using analysis. descriptiveThe analysis of data observation students at cycle i obtained the average percentage of the students only $50.044 \%$ ( low ) increased to percent of high 82.22 in cycle II. The spread of chief motivation students on cycle i obtained the average the percentage motivation students only of 59,75\% ( being ) increased to $71.5 \%$ ( high in cycle ii .Next based on hasi analysis student learning test study results obtained the average students on pre cycle of 62.167 (less of the total value 1492 with the ketuntasan klasikal is only $29.17 \%$, you are an increase of cycle $i$ with the average score of 67.667 ( less) while the up 37.5
\end{abstract}

Keywords: Motivation, Learning outcomes, Buzz Group

\begin{abstract}
Abstrak
Penelitian ini dilatarbelakangi oleh rendahnya motivasi dan hasil belajar pendidikan agama Islam siswa yang menempuh pendidikan di sekolah kejuruan. Tujuan penelitian ini untuk mengetahui Metode Pembelajaran Buzz dapat meningkatkan motivasi dan hasil belajar dalam belajar pendidikan agama Islam. Penelitian ini penelitian tindakan kelas (Class Room Action Research) yang dilaksanakan sebanyak dua siklus. Subjeknya siswa muslim Kelas XI Jurusan Pariwisata SMK Negeri 1 Terpadu Luwu Ponrang Selatan yang berjumlah 24 orang. Teknik pengumpulan data yang digunakan adalah observasi, Angket dan dengan menggunakan instrumen soal berbentuk pilihan ganda. Data yang diperoleh dianalisis menggunakan analisis deskriptif. Hasil analisis data observasi siswa pada siklus I diperoleh rata-rata persentase aktivitas siswa hanya sebesar 50.044\% (rendah) mengalami peningkatan menjadi sebesar $82.22 \%$ (tinggi) pada siklus II. Penyebaran angket motivasi siswa pada siklus I diperoleh ratarata persentase motivasi siswa hanya sebesar $59,75 \%$ (sedang) mengalami peningkatan menjadi $71.5 \%$ (tinggi) di siklus II. Selanjutnya berdasarkan hasi analisis tes belajar siswa diperoleh rata-rata hasil belajar siswa pada pra siklus sebesar 62.167 (kurang) dari total nilai 1492 dengan persentase ketuntasan klasikal hanya sebesar $29.17 \%$, selanjutnya mengalami peningkatan pada siklus I dengan skor rata-rata sebesar 67.667 (kurang) dan persentase ketuntasan klasikal 37.5.
\end{abstract}

Kata Kunci: Motivasi, Hasil Belajar, Buzz Group. 


\section{Pendahuluan}

Seiring dengan perkembangan zaman orientasi pendidikan pun berubah. Pendidikan sebelumnya hanya menitik beratkan pada penguasaan materi semata dengan pembelajaran satu arah yaitu guru sebagai subjek pembelajaran yakni pembelajaran yang berpusat pada guru (Teacher Centered Aproach). Sekarang sedikit demi sedikit proses pembelajaran seperti itu mulai diubah. Di masa sekarang bukan lagi proses pembelajaran yang berpusat pada guru, sehingga siswa tidak merasa bosan ketika belajar.

Dengan adanya inovasi pembelajaran seperti itu, maka mulai muncul pemikiran bahwa siswa sebagai objek pembelajaran sekaligus dapat menjadi subjek pembelajaran. Dalam hal ini, guru hanya menjadi fasilitator dalam pembelajaran, siswa yang banyak berperan aktif dalam kegiatan pembelajaran. Oleh karena itu, guru sebagai fasilitator dalam proses pembelajaran harus pintar dalam memilih metode dan sarana pembelajaran. Pemilihan tersebut harus sesuai dengan materi bahan ajar dan kondisi siswa itu sendiri. Sehingga siswa akan merasa nyaman dan termotivasi dalam belajar dan mampu meningkatkan hasil belajar siswa.

Selama proses pembelajaran, anak memerlukan motivasi. Peran motivasi dalam memperjelas tujuan belajar, erat kaitannya dengan pemaknaan belajar. Anak akan tertarik untuk belajar sesuatu jika yang dipelajari itu sedikitnya sudah dapat diketahui dan dinikmati manfaatnya bagi anak. Seorang anak yang telah termotivasi untuk belajar sesuatu, akan berusaha mempelajarinya dengan baik dan tekun, dengan harapan memperoleh hasil yang baik. Dalam hal itu, tampak motivasi untuk belajar menyebabkan seseorang tekun belajar. Sebaliknya, apabila seseorang kurang atau tidak memiliki motivasi untuk belajar, maka dia tidak tahan dalam belajar. Dia mudah tergoda untuk mengerjakan hal yang lain dan bukan belajar. Itu berarti motivasi sangat berpengaruh terhadap ketahanan dan

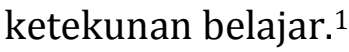

Di zaman modernisasi seperti sekarang ini, dalam dunia pendidikan membutuhkan seorang guru yang berkualitas yang tidak hanya memiliki kemampuan dalam mengajar namun mereka juga mampu memberikan motivasi jika siswa kurang termotivasi dalam belajar, khususnya dalam proses belajar mengajar pendidikan agama Islam.

Pendidikan Agama khususnya Pendidikan Agama Islam (PAI) merupakan suatu sumber nilai, sekaligus menjadi salah satu bidang studi yang ditawarkan dalam lembaga-lembaga pendidikan, baik dalam lembaga

\footnotetext{
${ }^{1}$ Abu Ahmadi dan Nur Uhbiyati, Ilmu Pendidikan. (Cet II; Jakarta: Rineka Cipta, 2001),
} h. $28-29$ 
pendidikan umum maupun lembaga pendidikan kejuruan terlebih dalam lembaga pendidikan Islam.

Pendidikan Agama Islam (PAI) memegang peran penting dalam pembangunan nilai-nilai Islam , oleh karena itu ada beberapa hal yang menjadi komponen di dalamnya, yakni guru pendidikan agama Islam sebagai agent of value (pembawa nilai), ilmu Islam sebagai nilai itu sendiri dan siswa sebagai messenger (penerjemah) dari nilai-nilai Islam dari seorang guru. ${ }^{2}$ Akan tetapi, sektor pendidikan yang merupakan alat untuk mencapai cita-cita saat ini terus mengalami berbagai persoalan yang mengakibatkan kemunduran dalam dunia pendidikan khususnya dalam pendidikan Agama Islam. Berbagai masalah terus bermunculan dan menggerogoti khususnya masalah rendahnya motivasi siswa dalam belajar agama Islam.

Mengingat pentingnya pendidikan agama Islam, maka sudah sewajarnya pendidikan agama Islam harus dikembangkan dan diperhatikan disetiap jenjang pendidikan. Namun dikalangan siswa telah beredar pemahaman bahwasanya Pendidikan Agama Islam merupakan mata pelajaran yang dianggap tidak penting khusuusnya siswa yang mengambil sekolah kejuruan.

Berdasarkan hasil observasi langsung serta wawancara dengan ibu Dasmawati selaku guru pendidikan agama Islam di SMK Negeri 1 Terpadu Luwu Ponrang Selatan, menyatakan bahwa "Siswa muslim yang ada di SMK Negeri 1 Terpadu Luwu Ponrang Selatan senderung merasa cuek dan kurang termotivasi dalam belajar pendidikan agama Islam. Mengingat mereka bersekolah di sekolah kejuruan, sehingga pelajaran agama di anggap sebelah mata oleh siswa sehingga siswa kurang berminat mendalami dan menyebabkan hasil belajar rendah."3 Oleh karena itu peneliti mencoba suatu metode pembelajaran baru dalam proses pembelajaran pendidikan agama Islam di SMK Negeri 1 Terpadu Luwu Ponrang Selatan khususnya pada siswa kelas XI Pariwisata.

Secara etimologi, metode berasal dari kata Method yang berarti suatu cara kerja yang sistematis untuk memudahkan pelaksanaan kegiatan dalam mencapai suatu tujuan. Apabila kata metode disandingkan dengan kata pembelajaran, maka berarti suatu cara atau sistem yang digunakan dalam pembelajaran yang bertujuan agar anak didik dapat mengetahui, memahami mempergunakan, menguasai bahan pelajaran tertentu. Dalam makna lain, metode pembelajaran diartikan sebagai prinsip-prinsip yang mendasari

${ }^{2}$ Malik Fajar, Madrasah dan Tantangan Modernitas, ( Bandung : Penerbit Mizan, 1998), h.3

${ }^{3}$ Dasmawati, Guru PAI SMK Terpadu Luwu Ponrang Selatan, Wawancara, Palopo 2 Januari 2016 
kegiatan mengarahkan perkembangan seseorang khususnya proses belajar mengajar. ${ }^{4}$

Ada literatur lain yang menelaskan tentang pengertian metode pembelajarana yaitu cara yang digunakan oleh guru untuk menyampaikan pelajaran kepada peserta didik. Karena penyampaian itu berlangsung dalam interaksi edukatif, metode pembelajaran dapat diartikan sebagai cara yang dipergunakan oleh guru dalam mengadakan hubungan dengan peserta didik pada saat berlangsungnya pengajaran. Dengan demikian, metode pembelajaran merupakan alat untuk menciptakan proses belajar-mengajar ${ }^{5}$

Metode Buzz Group merupakan diskusi kelas yang didalamnya dibagi kedalam kelompok-kelompok kecil untuk melaksanakan diskusi singkat tentang suatu problem atau permasalahan. ${ }^{6}$ Metode Buzz Group sangat mirip dengan metode huddle. Keduaduanya merupakan alat untuk membagi kelompok diskusi besar menjadi kelompok-kelompok kecil. Dan metode ini dikemukakan oleh pendidik dan ahli sosiologi Morgan pada tahun 1976.7 Selanjutnya menurut Hasibuan dan Moedijono menyatakan bahwa buzz group merupakani suatu kelompok besar dibagi menjadi beberapa kelompok kecil yang terdiri atas $4-5$ orang. 8

Bentuk diskusi ini terdiri dari kelas yang dibagi-bagi menjadi kelompok- kelompok kecil yang terdiri dari 4-6 orang peserta. Tempat duduk diatur sedemikian rupa agar para siswa dapat bertukar pikiran dan bertatap muka dengan mudah. Diskusi ini biaanya diadakan ditengah-tengah pelajaran atau diakhir pelajaran dengan maksud untuk memperjelas dan mempertajam kerangka bahan pelajaran atau sebagai jawaban terhadap pertanyaan- pertanyaan yang muncul ${ }^{9}$.

Menurut Hasibuan, dan Moedjiono Buzz group adalah suatu kelompok besar yang dibagi menjadi beberapa kelompok kecil, terdiri atas 4-5 orang. Tempat diatur agar siswa dapat berhadapan muka dan bertukar pikiran dengan mudah. Diskusi diadakan di tengah pelajaran atau diakhir

${ }^{4}$ Ahmad Munjin Nasih, Metode dan Teknik Pembelajaran Pendidikan Agama Islam, (Bandung: PT Refika Aditama, 2009), h. 29.

${ }^{5}$ Departemen Agama RI, Metodoulogi Pendidikan Agama Islam, (Jakarta: Direktorat Jendral

Kelembagaan Agama Islam, 2002), h. 88.

${ }^{6}$ Hisyam dkk, Strategi Pembelajaran Aktif, (Yogyakarta : Pustaka Insani Madani, 2008), $120-121$

${ }^{7}$ Suprijanto, Pendidikan Orang Dewasa, (Jakarta : PT. Bumi Aksara, 2007), h. 109-110.

${ }^{8}$ Hasibuan dan Moedjiono, Proses Belajar Mengajar, (Bandung : PT Rosda Karya, 2004), h. 20

${ }^{9}$ M Basyiruddin Usman. Metodologi pembelajaran Agama Islam, (Ciputat Pers, Jakarta, 2002). h. 40. 
pelajaran dengan maksud menajamkan kerangka bahan pelajaran, memperjelas bahan pelajaran atau menjawab pertanyaan-pertanyaan. ${ }^{10}$

Sedangkan Menurut Trianto "Buzz group sebagai suatu kelompok aktif yang terdiri dari 3-6 siswa untuk mendiskusikan ide siswa pada materi pelajaran". 11

Selain itu menurut Surjadi, Strategi buzz group adalah suatu kelompok dibagi kedalam beberapa kelompok kecil (sub groups) yang masing-masing terdiri dari 3-6 orang dalam tempo yang singkat, untuk mendiskusikan suatu topik/memecahkan suatu masalah seorang juru bicara ditunjuk untuk menyampaikan hasil diskusi kelompok masing-masing kepada sidang lengkap seluruh kelompok. ${ }^{12}$

\section{Langkah-Langkah Metode Pembelajaran Buzz Group ${ }^{13}$}

1. Pemimpin

a. Membantu dalam menentukan isu atau masalah.

b. Memecahkan kelompok ke dalam beberapa kelompok kecil yang terdiri dari 3-6 orang.

c. Memberikan penjelasan kepada kelompok-kelompok kecil tersebut yang meliputi :

1) Tentang tugasnya

2) Tentang batas waktu (5-15 menit) untuk menyelesaikan tugas

3) Menyarankan agar tiap kelompok kecil tersebut memilih sidang dan penulisannya.

d. Meminta saran-saran untuk memecahkan masalah penjelasan masalah atau menjawab pertanyaan-pertanyaan.

e. Mengunjungi kelompok demi kelompok untuk mengetahui apakah ada kelompok yang memerlukan bantuan dalam melaksanakan tugasnya.

f. Memperingatkan dua menit sebelumnya bahwa tugas mereka hamper berakhir.

g. Mengundang kelompok-kelompok kecil untuk berkumpul bersama lagi.

h. Mempersilahkan tiap kelompok menyampaikan laporan melalui juru bicara/laporannya.

i. Mempersilahkan tiap kelompok untuk menambahkan komentar terhadap laporan.

j. Merangkum hasil diskusi kelompok-kelompok tersebut atau menugaskan salah satu seorang untuk melakukannya.

k. Mengajukan tindakan atau studi tambahan.

l. Mengevaluasi manfaat dan kekurangan-kekurangan belajar.

2. Anggota-anggota Kelompok.

\footnotetext{
${ }^{10}$ Hasibuan dan Moedjiono, Proses Belajar Mengajar, (Bandung : PT Rosda Karya, 2004), h.20

${ }^{11}$ Trianto Ibnu Badar Al-Tabany, Mendesain Model Pembelajaran Inovatif, Progresif, dan Kontekstual, (Cet. II; Jakarta: Kencana, 2015), h.159.

${ }^{12}$ Surjadi, Membuat Siswa Aktif, ( Bandung: Bandar Maju, 1989 ), h. 34.

13 ibid h. 35-36.
} 
a. Membantu dalam merumuskan isu/masalah yang dihadapi mereka.

b. Ikut memilih pemimpin dan penulis dalam kelompok kecil.

c. Memperjelas/merumuskan suatu isu/masalah.

d. Menampilkan saran-saran untuk mendiskusikan isu/masalah.

e. Mendengarkan baik-baik dan menghargai sumbangan pendapat orang lain.

f. Mengembangkan pendapat atas dasar pendapat anggota-anggota lain.

g. Merumuskan bagaimana informasi itu dipergunakan dan dilaksanakan.

h. Ikut melaksanakan evaluasi efektivitas pengalaman belajar tersebut

3. Penulis (Sekertaris/Notulis)

a. Mencatat seluruh pendapat anggota-anggota kelompoknya

b. Merangkum pendapat-pendapat kelompoknya

c. Melaporkan kepada sidang lengkap.

Tabel. 1 Pelaksanaan Metode Diskusi Buzz Group ${ }^{14}$

\begin{tabular}{|c|c|c|}
\hline Tahapan & Uraian Tahapan & Kegiatan Guru \\
\hline Tahap 1 & $\begin{array}{l}\text { Mengatur tujuan dan } \\
\text { Mengatur setting }\end{array}$ & $\begin{array}{l}\text { Guru menyampaikan } \\
\text { tujuan pembelajaran } \\
\text { khusus dan } \\
\text { menyiapkan siswa untuk }\end{array}$ \\
\hline Tahap 2 & Mengarahkan diskusi & $\begin{array}{l}\text { Guru mengarahkan } \\
\text { fokus diskusi dengan } \\
\text { menguraikan aturan- } \\
\text { aturan dasar, mengajukan } \\
\text { pertanyaan-pertanyaan } \\
\text { awal, menyajikan situasi } \\
\text { yang tidak dapat segera }\end{array}$ \\
\hline Tahap 3 & Menyelenggarakan diskusi & $\begin{array}{l}\text { Guru memonitor } \\
\text { antar aksi, mengajukan } \\
\text { pertanyaan } \\
\text { mendengarkan gagasan } \\
\text { siswa, menanggapi } \\
\text { gagasan, melaksanakan } \\
\text { aturan dasar, membuat }\end{array}$ \\
\hline Tahap 4 & Mengakhiri diskusi & $\begin{array}{l}\text { Guru menutup diskusi } \\
\text { dengan merangkum atau } \\
\text { mengungkapkan makna } \\
\text { diskusi yang telah } \\
\text { diselenggarakan kepada }\end{array}$ \\
\hline
\end{tabular}

${ }^{14}$ Trianto, Model Pembelajaran Inovatif Berorientasi Konstruktivistif, (Jakarta : Prestasi Pustaka, 2007), h. 125 


\begin{tabular}{|l|l|l|}
\hline Tahap 5 & $\begin{array}{l}\text { Melakukan Tanya jawab } \\
\text { singkat tentang proses diskusi } \\
\text { itu }\end{array}$ & $\begin{array}{l}\text { Guru menyuruh para } \\
\text { siswa untuk memeriksa } \\
\text { proses diskusi dan siswa } \\
\text { berfikir. }\end{array}$ \\
\hline
\end{tabular}

Penelitian ini bertujuan untuk mengetahui Apakah Metode Pembelajaran Buzz Group (Diskusi Kelompok Kecil) dapat meningkatkan motivasi dan hasil belajar Siswa Kelas XI Pariwisata SMK Negeri 1 Terpadu Luwu Ponrang Selatan dalam belajar pendidikan agama Islam.

\section{Metode Penelitian}

Penelitian ini merupakan penelitian tindakan kelas (Classroom Action Research) dengan subjek penelitian adalah peserta didik kelas VIII Pesantren Modern Datok Sulaiman Bagian Putra Palopo yang berjumlah 28 orang. Teknik pengumpulan data dalam penelitian ini dilakukan dengan beberapa teknik yaitu Observasi dan Tes. Setelah diperoleh data serta sajiannya, dilakukan penilaian keberhasilan tindakan. Penilaian keberhasilan tindakan ditentukan sesuai dengan data yang terkumpul. Adapun rumus yang digunakan yaitu:

Jenis penelitian yang digunakan pada penelitian ini adalah penelitian tindakan kelas (Class Room Action Researcch) yang dilakukan secara partisipatif dan kolaboratif yang bertujuan untuk meningkatkan hasil belajar matematika siswa Penelitian ini dilaksanakan dalam siklus-siklus dan akan dihentikan jika sudah memenuhi idikator keberhasilan. Menurut Kemmis dan Mc Taggrat ada empat tahap dalam penelitian tindakan kelas (PTK) yaitu: ${ }^{15}$

1. Perencanaa (Planning)

2. Tindakan (Action)

3. Pengamatan (Observation)

4. Refleksi (Reflection)

Lokasi penelitian ini adalah di SMK Negeri 1 Terpadu Luwu Ponrang Selatan di jalan poros Belopa Palopo KM 12 Pattedong Kecamatan Ponrang Selatan Kabupaten Luwu Provinsi Sulawesi Selatan dalam belajar pendidikan agama Islam. Subjek dalam penelitian ini adalah seluruh siswa kelas XI Pariwisata SMK Negeri 1 Terpadu Luwu Ponrang Selatan, yang terdiri atas 24 siswa. Teknik pengumpulan data yang digunakan adalah: Observasi, Angket, Tes dan Interview (Wawancara). Hasil observasi aktifitas siswa dan

\footnotetext{
${ }^{15}$ Suharsimi, et.al., Penelitian Tindakan Kelas, (Cet. X; Jakarta : PT Bumi Aksara, 2011),
} h. 16 . 
angket motivasi siswa dianalisis secara kualitatif deskriptif yang diolah dengan teknik persentase dengan menghitung persentase siswa yang terlibat aktif.

Tabel. 2 Kriteria Pengkategorian Hasil Belajar ${ }^{16}$

\begin{tabular}{|c|c|}
\hline Skor & Kategori \\
\hline $0.00-59.99$ & Sangat Kurang \\
\hline $60.00-69.99$ & Kurang \\
\hline $70.00-79.99$ & Cukup \\
\hline $80.00-89.99$ & Tinggi \\
\hline $90.00-100$ & Sangat Tinggi \\
\hline
\end{tabular}

\section{Hasil Penelitian}

Deskripsi Hasil Analisis Siklus I

Ada beberapa tahap yang dilakukan pada pelaksanaan siklus I yaitu tahap perencanaan, tahap pelaksanaan, tahap observasi dan evaluasi, serta tahap refleksi.

1. Tahap Perencanaan

Pada tahap ini peneliti mempersiapkan materi-materi pelajaran yang akan dibahas pada siklus I. Selain itu peneliti membuat perangkat pembelajaran yang sesuai dengan metode pembelajaran buzz (kelompok kecil) untuk setiap kali pertemuan. Selain itu peneliti mempersiapkan lembar observasi untuk mencatat aktivitas siswa selama proses belajar mengajar di kelas serta membuat angket yang dapat mengukur motivasi siswa dalam belajar pendidikan agama Islam setelah penggunaan metode buzz group (kelompok kecil) berlangsung dan serta mendesain alat evaluasi untuk melihat hasil belajar siswa berdasarkan materi yang telah diberikan. Hal utama yang dilakukan peneliti pda tahap ini adalah mempelajari bahan yang akan diajarkan dari berbagai sumber.

2. Tahap Pelaksanaan Tindakan

Memasuki tahap pelaksanaan tindakan, peneliti melaksanakan tindakan berdasarkan rencana pembelajaran yang telah disiapkan yaitu mengikuti langkah-langkah pembelajaran dengan menggunakan metode buzz group (kelompok kecil). Langkah pertama yang harus dlakukan oleh guru adalah membagi siswa menjadi beberapa kelompok kecil. Dalam penelitian ini terbentuk enam kelompok dengan jumlah peserta empat siswa. Pada masingmasing kelompok guru memberikan kebebasan kepada masing-masing siswa

\footnotetext{
${ }^{16}$ Iqbal hasan, Pokok-pokok Materi statistik 1 (Statistik Deskriptif), (Cet. I; Edisi ke II; Jakarta: Bumi Aksara, 2002), h. 34.
} 
dalam menentukan pemimpin, penulis, dan anggota-anggotanya. Guru kemudian akan menjelaskan tugas dari masing-masing peserta dalam suatu kelompok.

Siklus I dilaksanakan selama empat pertemuan, tiga pertemuan digunakan untuk kegiatan belajar mengajar dan satu pertemuan digunakan untuk mengetes hasil belajar siswa selama proses pembelajaran dengan menggunakan metode buzz group. Selama proses pembelajaran dengan menggunakan metode buzz group (kelompok kecil) setiap kelompok akan diamati dengan menggunakan lembar observasi aktivitas siswa yang memuat indikator-indikator motivasi siswa dalam belajar pendidikan agama Islam. Di akhir pertemuan pada siklus I siswa akan diberikan tes dan juga angket untuk mengukur peran metode buzz group (kelompok kecil) dan membandingkan dengan motivasi yang timbul dari diri siswa selama proses pembelajaran tersebut.

3. Tahap Observasi dan Evaluasi

Tahap observasi pada siklus I tercatat sikap yang terjadi pada setiap siswa selama proses pembelajaran pendidikan agama Islam dengan menggunakan metode buzz group (kelompok kecil). Observasi terhadap aktivitas siswa dilakukan untuk mengukur motivasi belajar siswa selama proses pembelajaran berlangsung. Kegiatan observasi dilakukan di setiap pertemuan selama proses pembelajaran pendidikan agama Islam berlangsung. Adapun rekapitulasi hasil observassi aktivtas siswa selama peroses pembelajaran di siklus I dapat dilihat melalui tabel berikut ini:

Tabel 3. Rekapitulasi Hasil Observasi aktivitas siswa selama proses pembelajaran PAI Pada Siklus I

\begin{tabular}{|c|c|c|c|}
\hline \multirow{2}{*}{ Kelompok } & \multicolumn{3}{|c|}{ Persentase Aktivitas Siswa Pertemuan ke- } \\
\cline { 2 - 4 } & $\mathbf{1}$ & $\mathbf{2}$ & $\mathbf{3}$ \\
\hline I & 32 & 53.3 & 62.7 \\
\hline II & 34.7 & 54.7 & 61.3 \\
\hline III & 36 & 53.3 & 62.7 \\
\hline IV & 34.7 & 52 & 64 \\
\hline V & 33.3 & 53.3 & 62.7 \\
\hline VI & 34.7 & 54.7 & 62.7 \\
\hline
\end{tabular}

Hasil analisis pada tabel 4 merupakan analisis data hasil observasi aktifitas siswa untuk setiap kelompok yang terbentuk melalui lembar observasi yang telah dibuat pada siklus I. Kegiatan observasi dilakukan perkelompok dalam setiap pertemuan. Karena proses pembelajaran pada 
siklus I berlangsung sebanyak tiga pertemuan maka kegiatan observasi dilakukan sebanyak tiga kali per kelompok. Hasil observasi dianalisis dalam bentuk persentase untuk setiap pertemuan dan perkelompok seperti pada tabel diatas. Berdasarkan tabel diatas diperoleh rata-rata persentase aktifitas enam kelompok siswa dari apek motivasi selama tiga kali pertemuan adalah sebesar 50.04\% dan termasuk dalam kategori rendah.

Setelah pelaksanaan tindakan dengan menggunakan metode buzz group (kelompok kecil), maka pada siklus I siswa diminta untuk mengisi angket yang memuat pernyataan-pernyataan untuk mengukur motivasi siswa dalam belajar pendidikan agama Islam. Hasil rekapitulasi skoring dari angket motivasi belajar siswa diperoleh $59,75 \%$ yang masuk dalam kategori sedang.

Di akhir pertemuan pada siklus I, siswa kelas XI Pariwisata SMK Negeri 1 Terpadu Luwu Ponrang Selatan diberi tes yang disebut juga tes siklus I. Adapun hasil analisis deskriptif untuk hasil tes siklus I dapat dilihat pada tabel berikut.

Tabel 4 Deskripsi Hasil Tes Siklus I

\begin{tabular}{|c|c|}
\hline Statistik & Nilai Statistik \\
\hline Rata-rata & 67.667 \\
\hline Nilai Tengah & 66 \\
\hline Modus & 64 \\
\hline Standar Deviasi & 13.1832 \\
\hline Variansi & 173.789 \\
\hline Nilai tertinggi & 88 \\
\hline Nilai terendah & 40 \\
\hline Rentang Nilai & 48 \\
\hline Total Nilai & 1624 \\
\hline
\end{tabular}

Tabel 5 Pengkategorisasian Hasil Tes Siklus I

\begin{tabular}{|c|c|c|c|c|}
\hline No. & Interval Skor & Kategori & Jumlah & $\begin{array}{l}\text { Persentase } \\
(0 /)\end{array}$ \\
\hline 1 & $0.00-59.99$ & Sangat Kurang & 4 & $16.67 \%$ \\
\hline 2. & $60.00-69.99$ & Kurang & 11 & $45.83 \%$ \\
\hline 3. & $70.00-79.99$ & Cukup & 3 & $12.50 \%$ \\
\hline 4. & $80.00-89.99$ & Tinggi & 6 & $25.00 \%$ \\
\hline 5 & $90.00-100$ & Sangat Tinggi & 0 & $0.00 \%$ \\
\hline \multicolumn{3}{|c|}{ Jumlah } & 24 & $100 \%$ \\
\hline
\end{tabular}


Untuk lebih jelasnya hasil tes pada siklus I dapat dilihat pada diagram batang berikut.

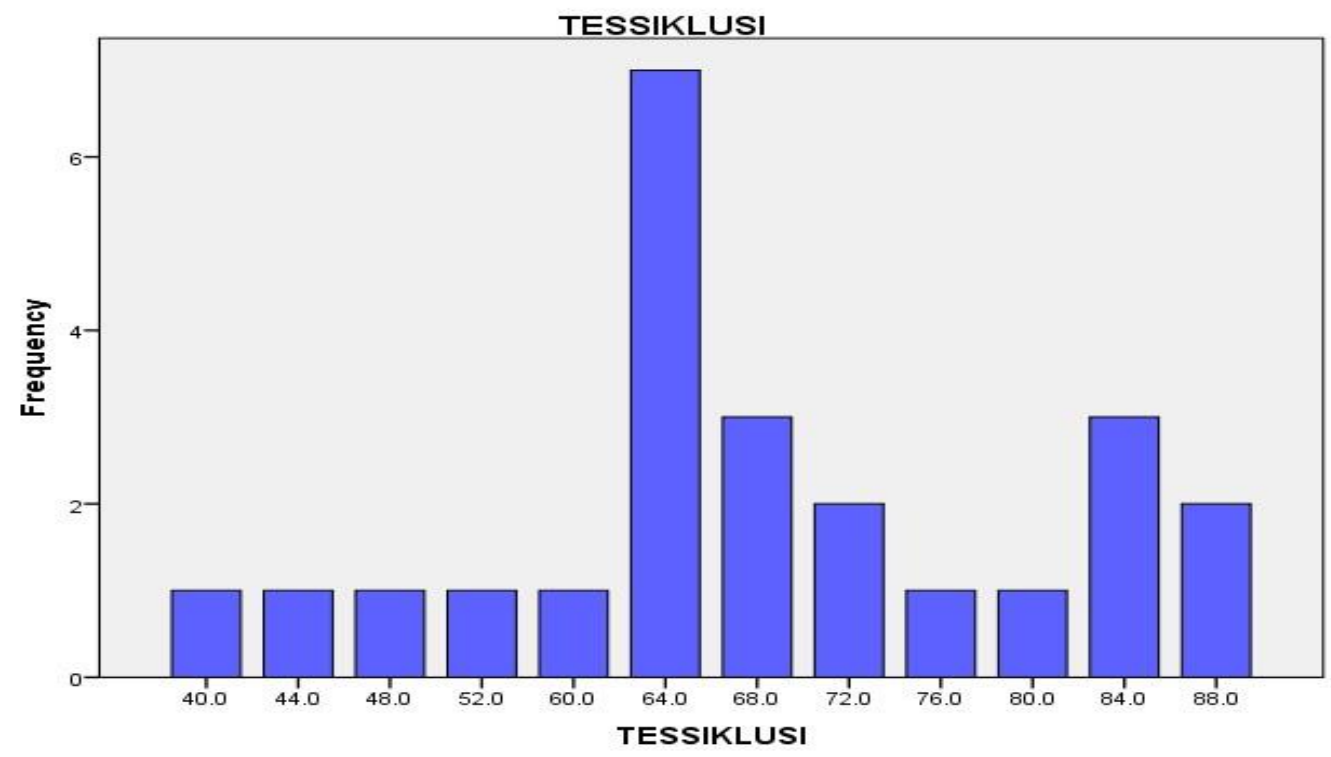

Gambar 1 Diagram Hasil Tes Siklus I

Apabila hasil belajar siswa dipaparkan dalam kriteria ketuntasan hasil belajar secara klasikal pada siklus I dapat dilihat pada tabel berikut:

Tabel 6 Persentase Ketuntasan Hasil Belajar Siklus I

\begin{tabular}{|c|c|c|c|}
\hline Rentang Skor & Kategori & Frekuensi & Persentase \\
\hline $70.00-100$ & Tuntas & 9 & $37.5 \%$ \\
\hline $0-69.99$ & Tidak Tuntas & 1 & $62.5 \%$ \\
\hline \multicolumn{2}{|c|}{ Jumlah } & $\mathbf{2}$ & $\mathbf{1 0 0 \%}$ \\
\hline
\end{tabular}

\section{Tahap Refleksi Siklus I}

Dari berbagai rangkaian kegiatan pada siklus I dapat dilihat keterkaitan masing-masing kegiatan. Berdasarkan hasil refleksi yang dilakukan guru dan peneliti diperoleh pemahaman bahwa penerapan metode buzz group berperan dalam meningkatkan motivasi siswa dalam belajar pendidikan agama Islam khususnya bagi siswa kelas XI Pariwisata SMK Negeri 1 Terpadu Luwu Ponrang Selatan.

Dari hasil observasi pada siklus I diperoleh kesimpulan bahwa ratarata motivasi siswa selama proses pembelajaran pada siklus I sebesar $50.044 \%$ dan hanya termasuk dalam kategori motivasi yang rendah. Untuk memperkuat hasil observasi maka peneliti menyebarkan angket kepada subjek penelitian yang memuat butir-butir pernyataan yang dapat mengukur motivasi siswa dalam belajar. Berdasar pada hasil analisis skor 
perolehan angket diperoleh kesimpulan bahwa rata-rata tingkat motivasi siswa dalam proses pembelajaran dengan menggunakan metode buzz group pada siklus 1 sebesar 59,75\% dan termasuk dalam kategori sedang.

Selanjutnya berdasarkan hasil analisis tes belajar siswa pada mata pelajaran pendidikan agama Islam di akhir siklus I menunjukan bahwa penggunaan metode pembelajaran buzz group pada sisklus I mengakibatkan rata-rata hasil belajar siswa adalah sebesar 67.667 dan termasuk dalam kategori kurang. dengan persentase ketuntasan hanya sebesar 37.5\%.

Berdasarkan hasil penelitian yang diperoleh pada siklus I belum dapat dipastikan secara umum bahwa metode pembelajaran buzz group berperan dalam meningkatkan motivasi dan hasil belajar pendidikan agama Islam khususnya bagi siswa kelas XI Pariwisata SMK Negeri 1 Terpadu Luwu Ponrang Selatan. Oleh Karena itu kegiatan penelitian ini perlu dilanjutkan kesiklus berikutnya.

\section{Deskripsi Hasil Analisis Siklus II}

Sama halnya dengan pelaksanaan siklus I, pada siklus II ini ada beberapa tahap yang dilakukan yaitu tahap perencanaan, tahap pelaksanaan, tahap observasi dan evaluasi, serta tahap refleksi.

1. Tahap Perencanaan

Persiapan yang dilakukan pada tahap perencanaan tindakan siklus II ini hampir sama dengan siklus I. Hanya saja catatan dari hasil refleksi siklus I menjadi pertimbangan dalam perencanaan tindakan ini. Pada tahap perencanaan siklus II, peneliti kembali menyediakan RPP, lembar observasi, angket motivasi, serta tes hasil belajar.

2. Tahap Pelaksanaan Tindakan

Pelaksanaan pembelajaran siklus II ini hamper sama dengan siklus I. Hanya saja ada perbaikan-perbaikan sesuai dengan hasil refleksi siklus I. Pada siklus II masih menggunakan kelompok yang sama seperti pada siklus I.

Siklus II terdiri dari empat pertemuan, tiga pertemuan merupakan proses belajar mengajar dengan menggunakan metode buzz group dan satu pertemuan digunakan untuk mengevaluasi siswa setelah penggunaan metode buzz group.

Selama proses pembelajaran siswa juga diamati menggunakan lembar observasi yang sama seperti pada siklus I. Setelah itu siswa diberI tes dan juga angket untuk mengetahui motivasi siswa dalam belajar pendidikan agama Islam dengan menggunakan metode buzz group.

3. Tahap Observasi dan Evaluasi

Tahap observasi pada siklus II dilakukan untuk mengetahui sikap yang terjadi pada setiap siswa selama proses pembelajaran pendidikan agama Islam dengan menggunakan metode buzz group (kelompok kecil). Observasi terhadap aktivitas siswa dilakukan untuk mengukur motivasi 
belajar siswa selama proses pembelajaran berlangsung pada siklus II. Kegiatan observasi dilakukan di setiap pertemuan pada siklus II selama proses pembelajaran pendidikan agama Islam berlangsung.

Adapun rekapitulasi hasil observassi aktivtas siswa selama peroses pembelajaran di siklus II dapat dilihat melalui tabel berikut ini:

Tabel 7 Rekapitulasi Hasil Observasi aktivitas siswa selama proses pembelajaran PAI Pada Siklus I

\begin{tabular}{|c|c|c|c|}
\hline \multirow{2}{*}{ Kelompok } & \multicolumn{3}{|c|}{$\begin{array}{c}\text { Persentase Aktivitas Siswa } \\
\text { Pertemuan ke- }\end{array}$} \\
\cline { 2 - 4 } & $\mathbf{1}$ & $\mathbf{2}$ & $\mathbf{3}$ \\
\hline I & 69 & 84 & 91 \\
\hline II & 71 & 88 & 91 \\
\hline III & 69 & 89 & 95 \\
\hline IV & 68 & 84 & 93 \\
\hline V & 65 & 84 & 92 \\
\hline VI & 68 & 85 & 93 \\
\hline
\end{tabular}

Berdasarkan hasil observasi diperoleh kesimpulan bahwa motivasi siswa dalam belajar pendidikan agama Islam dengan menggunakan metode buzz group telah mengalami peningkatan dari siklus I yang rata-rata persentase aktivitas siswa yang hanyalah sebesar $50.044 \%$ meningkat 32.176\% menjadi $82.22 \%$ pada siklus II.

Deskripsi hasil analisis angket pada siklus II menunjukan bahwa penggunaan metode pembelajaran buzz group dalam proses belajar mengajar pendidikan agama Islam berperan dalam meningkatkan motivasi siswa. Hal ini dapat dilihat melalui peningkatan rata-rata persentase motivasi siswa yang di ukur melalui angket trus mengalami peningkatan dari $58.75 \%$ pada siklus I menigkat sebesar $12.75 \%$ menjadi $71.5 \%$ pada siklus II.

Adapun hasil analisis deskriptif untuk hasil tes siklus II dapat dilihat pada tabel berikut.

Tabel 8 Deskripsi Hasil Tes Siklus II

\begin{tabular}{|c|c|}
\hline Statistik & Nilai Statistik \\
\hline Rata-rata & 80.833 \\
\hline Nilai Tengah & 78 \\
\hline Modus & 76 \\
\hline Standar Deviasi & 11.4954 \\
\hline Variansi & 132.145 \\
\hline Nilai tertinggi & 100 \\
\hline
\end{tabular}




\begin{tabular}{|c|c|}
\hline Nilai terendah & 60 \\
\hline Rentang Nilai & 40 \\
\hline Total Nilai & 1940 \\
\hline
\end{tabular}

Hasil analisis deskriptif diatas menunjukan bahwa penggunaan metode pembelajaran buzz group pada sisklus II mengakibatkan rata-rata hasil belajar siswa adalah sebesar 80.833 dengan total nilai 1940 dari 24 subjek penelitian. Apabila nilai hasil tes siklus II dikelompokkan dalam empat kategori maka diperoleh persentase hasil seperti tabel berikut:

Tabel 9 Pengkategorisasian Hasil Tes Siklus II

\begin{tabular}{|c|l|l|c|l|}
\hline No. & Interval Skor & \multicolumn{1}{|c|}{ Kategori } & Jumlah & $\begin{array}{c}\text { Persentas } \\
\text { e }\end{array}$ \\
\hline 1. & $0.00-59.99$ & Sangat Kurang & 0 & $0.00 \%$ \\
\hline 2. & $60.00-69.99$ & Kurang & 3 & $12.50 \%$ \\
\hline 3. & $70.00-79.99$ & Cukup & 9 & $37.50 \%$ \\
\hline 4. & $80.00-89.99$ & Tinggi & 5 & $20.83 \%$ \\
\hline 5. & $90.00-100$ & Sangat Tinggi & 7 & $29.17 \%$ \\
\hline Jumlah & 24 & $100 \%$ \\
\hline \multicolumn{5}{|l|}{ Berdasarkan hasil pengkategorisasian hasil tes siklus II yang }
\end{tabular}

dipaparkan pada tabel diatas diperoleh hasil rata-rata persentase hasil belajar siswa adalah sebesar $0.00 \%$ termasuk dalam kategori sangat kurang, sebesar $12.50 \%$ berada pada kategori kurang dengan frekuensi 3 siswa, sebesar $37.50 \%$ termasuk dalam kategori cukup dengan frekuensi 9 siswa, sebesar $20.83 \%$ termasuk dalam kategori tinggi dengan frekuensi sbesar 5 siswa dan sebesar 29.16\% termasuk dalam kategori sangat tinggi dengan frekuensi 7 siswa . 


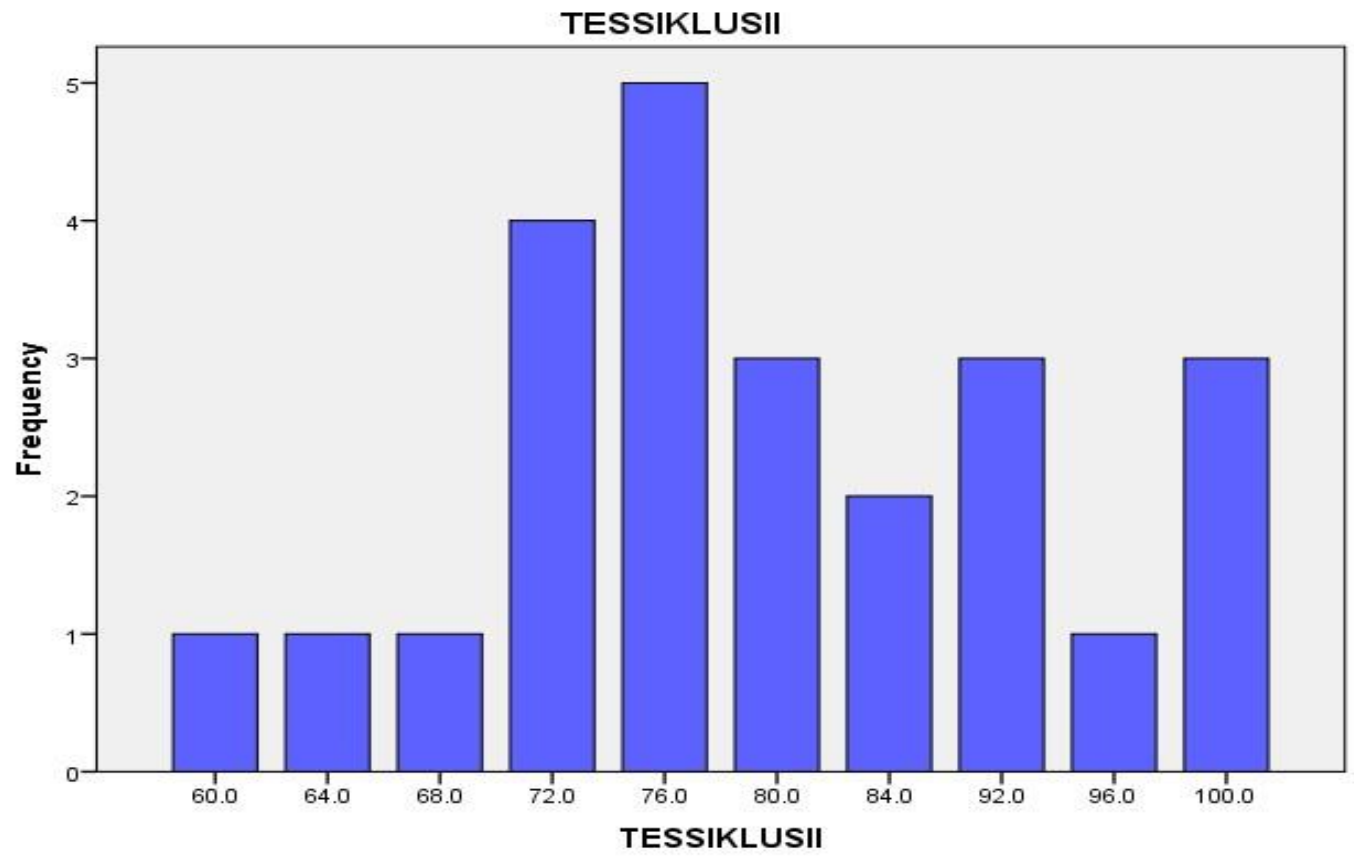

Gambar 2 Diagram Hasil Tes Siklus II

Apabila hasil belajar siswa dipaparkan dalam kriteria ketuntasan hasil belajar secara klasikal pada siklus I dapat dilihat pada tabel berikut:

Tabel 10 Persentase Ketuntasan Hasil Belajar Siklus II

\begin{tabular}{|c|c|c|c|}
\hline Rentang Skor & Kategori & Frekuensi & Persentase \\
\hline $70.00-100$ & Tuntas & 2 & $87.5 \%$ \\
\hline $0-69.99$ & Tidak Tuntas & 3 & $12.5 \%$ \\
\hline
\end{tabular}

\section{Pembahasan}

Aktivitas pembelajaran dilakukan bertujuan untuk meningkatkan keberhasilan belajar peserta didik setelah mengalami proses pembelajaran. Salah satu upaya yang dilakukan untuk mencapai keberhasilan pembelajaran agar efektif dan efesien, yakni penggunaan metode pembelajaran yang sesuai dengan materi yang diajarkan. Dalam mengajarkan mata pelajaran Akidah Akhlak khususnya pada materi beriman kepada kitab-kitab Allah Swt dibutuhkan metode yang membantu peserta didik memahami konsep dan beriman kepada kitab-kitab Allah Swt dengan baik dan benar. Oleh karena itu, penggunaan model pembelajaran kooperatif tipe Jigsaw diharapkan mampu memberi pengetahuan dan pemahaman lebih bagi peserta didik melalui pengalaman langsung. Model pembelajaran kooperatif tipe Jigsaw adalah model pemberian kesempatan kepada peserta didik perorangan atau 
kelompok untuk dilatih melakukan suatu pembuktian kebenaran suatu teori. Dengan penerapan model pembelajaran kooperatif tipe Jigsaw pembelajaran akan lebih efektif. 17

Sebelum pelaksanaan penelitian terlebih dahulu peneliti melakukan observasi awal dan mengumpulkan data-data yang dapat mendukung pelaksanaan penelitian ini berupa data hasil belajar siswa berbentuk dokumentasi hasil mid semester siswa. Hasil analisis data tersebut menunjukan bahwa rata-rata hasil belajar siswa sebelum penerapan metode buzz group (Diskusi Kelompok Kecil) adalah sebesar 62.167 dengan total nilai 1492 dari 24 subjek penelitian. Berdasarkan hasil pengkategorisasian diperoleh hasil bahwa rata-rata persentase hasil belajar siswa sebesar $29.17 \%$ berada pada kategori sangat kurang dengan frekuensi 7 siswa, sebesar 41.67\% termasuk dalam kategori kurang dengan frekuensi 10 siswa, sebesar $20.83 \%$ termasuk dalam kategori cukup dengan frekuensi 5 siswa, sebesar 8.33\% dalam kategori tinggi dengan frekuensi 2 siswa dan sebesar $0 \%$ sangat tinggi dengan frekuensi 0 siswa. Selain itu Hasil belajar siswa pada pra siklus belum mencapai persentase criteria ketuntasan minimal siswa dimana hanya terdapat 7 siswa yang tuntas dalam belajar dengan persentase $29.17 \%$ dan sebanyak 17 siswa yang tidak tuntas dengan persentase $70.83 \%$.

Hasil analisi tersebut memperkuan dugaan penulis bahwa Siswa Kelas XI Pariwisata SMK Negeri 1 Terpadu Luwu Ponrang Selatan perlu diberikan tindakan khusus dengan cara membuat siswa lebih aktif selama proses pembelajaran melalui penerapan metode buzz group (Diskusi Kelompok Kecil) hal ini diharapkan dapat meningkatkan motivasi dan hasil belajar siswa.

Penelitian ini dilaksanakan sebanyak delapan kali pertermuan yang terdiri dari dua siklus. Masing-masing siklus terdiri dari empat pertemuan, tiga pertemuan digunakan untuk proses belajar mengajar dan satu pertemuan untuk tes hasil belajar. Penelitian ini diawali dengan melakukan observasi awal dan wawancara dengan guru pendidikan agama Islam di lokasi penelitin. Obsrvasi dan wawancara dilakukan untuk menegtahui kondisi awal siswa dalam penelitian ini yaitu motivasi dan hasil belajar siswa sebelum dilakukan tindakan penelitian.

Pada tahap perencanaan di siklus I segala sesuatu yang digunakan dalam proses pembelajaran dengan menggunakan metode Pembelajaran Buzz Group (Diskusi Kelompok Kecil) perlu disediakan sedemikian rupa. Adapun hal-hal yang disediakan seperti materi pembelajaran, lembar observasi, angket, daan tes hasil belar untuk siswa. Dari hasil observasi pada siklus I diperoleh bahwa rata-rata persentase aktivitas siswa apabila dilihat dari

17 Ismail Sukardi, Model dan Metode Pembelajaran Modern: Suatu Pengantar, (Palembang: Tunas Gemilang Press, 2011), h. 28 
aspek motivasi hanyalah sebesar $50.044 \%$ dan termasuk dalam kategori rendah. Selanjutnya berdasarkan hasil analisis angket yang dilakukan pada siklus I diperoleh kesimpulan bahwa rata-rata tingkat motivasi siswa pada siklus I hanya sebesar 59,75\% dan termasuk dalam kategori sedang. Dan apabila dikaitkan dengan tes hasil belajar siswa diperoleh rata-rata hasil belajar siswa adalah sebesar 67.667 dengan total nilai 1624 dari 24 subjek penelitian dengan rata-rata persentase hasil belajar siswa adalah sebesar $16.67 \%$ termasuk dalam kategori sangat rendah dengan frekuansi 4 siswa, sebesar $45.83 \%$ berada pada kategori rendah dengan frekuensi 11 siswa, sebesar $12.50 \%$ termasuk dalam kategori cukup dengan frekuensi 3 siswa, sebesar $25.00 \%$ termasuk dalam kategori tinggi dengan frekuensi 6 siswa dan sebesar $0.00 \%$ dalam kategori sangat tinggi dengan frekuensi 0 siswa. Selanjutnya apabila dikaitkan dengan ketuntasan klasikal maka hanya terdapat 9 siswa yang tuntas dalam belajar dengan persentase $37.5 \%$ dan sebanyak 15 siswa yang tidak tuntas dengan persentase $62.5 \%$. Hasil analisis tes hasil belajar siswa pada siklus I sedikit telah mengalami peningkatan dari hasil pra siklus, akan tetapi persentase ketuntasan klasikal siswa belum tercapai sehingga harus dilanjutkan kesiklus II.

Berdasarkan hasil penelitian yang diperoleh pada siklus I belum dapat dipastikan secara umum bahwa metode pembelajaran buzz group dapat meningkatkan motivasi dan hasil belajar siswa dalam pendidikan agama Islam khususnya bagi siswa kelas XI Pariwisata SMK Negeri 1 Terpadu Luwu Ponrang Selatan. Oleh Karena itu kegiatan penelitian ini perlu dilanjutkan kesiklus berikutnya.

Siklus II dilakukan bedasarkan hasil refleksi dari siklus I, kesalahankesalahan yang timbul pada siklus I, akan diperbaiki pada siklus II. Peneliti tetap menyediakan berbagai instrument pada siklus II sama halnya pada siklus I.

Pelaksanaan pembelajaran siklus II ini hamper sama dengan siklus I. Hanya saja ada perbaikan-perbaikan sesuai dengan hasil refleksi siklus I. Pada siklus II masih menggunakan kelompok yang sama seperti pada siklus I.

Berdasarkan hasil observasi pada siklus II diperoleh rata-rata persentase aktivitas siswa apabila dilihat dari aspek motivasi telah mengalami peningkatan dari siklus I yang hanyalah sebesar 50.044\% dan termasuk dalam kategori rendah. Pada siklus II rata-rata persentase aktivitas siswa apabila dilihat dari aspek motivasi menjadi sebesar $82.22 \%$ dan termasuk dalam kateori tinggi. rata-rata. Selain itu berdasarkan hasil analisis penyebaran diperoleh rata-rata perentase tingkat motivasi siswa pada siklus 1I sebesar 71.5\% dan termasuk dalam kategori tinggi.

Selanjutnya hasil analisis deskriptif tes hasil belajar siswa pada siklus II menunjukan bahwa penggunaan metode pembelajaran buzz group pada 
sisklus II mengakibatkan rata-rata hasil belajar siswa adalah sebesar 80.833 dengan total nilai 1940 dari 24 subjek penelitian. Berdasarkan hasil pengkategorisasian hasil tes siklus II diperoleh hasil rata-rata persentase hasil belajar siswa adalah sebesar $0.00 \%$ termasuk dalam kategori sangat kurang, sebesar $12.50 \%$ berada pada kategori kurang dengan frekuensi 3 siswa, sebesar $37.50 \%$ termasuk dalam kategori cukup dengan frekuensi 9 siswa, sebesar 20.83\% termasuk dalam kategori tinggi dengan frekuensi sbesar 5 siswa dan sebesar $29.16 \%$ termasuk dalam kategori sangat tinggi dengan frekuensi 7 siswa. Selain itu apabila dikaitkan dengan kriteriaa ketuntasan klasikal diperoleh bahwa terdapat 21 siswa yang tuntas dalam belajar dengan persentase $87.5 \%$ dan hanya ada 3siswa yang tidak tuntas dengan persentase $12.5 \%$.

Secara umum selama siklus II kegiatan pembelajaran berjalan dengan sangat baik, hal ini dapat dilihat dari perubahan motivasi siswa dalam mengikuti proses pembelajaran dengan menggunakan metode pembelajaran buzz group selain itu hasil elajar siswa juga terus mengalami peningkatan. Apabila dikaitkan dengan hasil analisis pra siklus, siklus I dengan siklus II, maka diperoleh kesimpulan umum bahwa metode pembelajaran buzz group (diskusi kelompok kecil) mampu meningkatkan motivasi da hasil belajar pendidikan agama Islam khususnya bagi siswa kelas XI Pariwisata SMK Negeri 1 Terpadu Luwu Ponrang Selatan.

\section{Penutup}

Metode pembelajaran Buzz Group (Diskusi Kelompok Kecil) berperan dalam meningkatkan motivasi dan hasil belajar Siswa Kelas XI Pariwisata SMK Negeri 1 Terpadu Luwu Ponrang Selatan dalam belajar pendidikan agama Islam. Dari hasil analisis tes belajar siswa pada pra siklus diperoleh rata-rata hasil belajar siswa adalah sebesar 62.167 termasuk dalam kategori kurang dari total nilai 1492 dengan persentase ketuntasan klasikal hanya sebesar $29.17 \%$. Selanjutnya hasil belajar siswa terus mengalami peningkatan pada siklus I dengan skor rata-rata hasil belajar siswa adalah sebesar 67.667 namun masih dalam kategori kurang dengan total nilai 1624 dengan persentase ketuntasan klasikal 37.5\%. Selanjutnya pada siklus II diperoleh rata-rata hasil belajar siswa adalah sebesar 80.833 dan termasuk dalam kategori tinggi dengan total nilai 1940 dengan persentase ketuntasan klasikal sebesar 87.5\%. Secara umum dapat disimpulkan bahwa apabila motivasi siswa dalam belajar mengalami peningkatan maka hasil belajar juga akan mengalami peningkat

\section{Daftar Pustaka}

Abror, Rahman, Psikologi Pendidikan, Yogyakarta : Tiara Wacana, 1993. 
Ahmadi, Abu dan Nur Uhbiyati, Ilmu Pendidikan. Cet II; Jakarta: Rineka Cipta, 2001.

Arpanto,Pius , M. Dahlan Albarry, Kamus Ilmiah Populer, Surabaya: Arkola, 1994. Arifin, Filsafat pendidikan Islam, Jakarta : Bina Aksara, 1987.

Bahri Djamarah, Syaiful dan Aswan Zain. Strategi belajar Mengajar. Cet. I; Jakarta: Rineka Cipta, 1997.

Damayati \& Mudjiono, Belajar \& Pembelajaran, Cet. III; Jakarta: Rineka Cipta, Februari 2006.

Darajhat,Zakiah dkk., Ilmu Pendidikan Islam, Jakarta: Bumi Aksara, 2000. Daradjat,Zakiah Pendidikan Islam Dalam Keluarga dan Sekolah, Cet. III: Jakarta : Ruhama, 1995.

Dirjen Pendidikan Islam, UU RI Tahun 2005 Tentang Guru Dan Dosen serta UU RI. No. 20 Tahun 2003 Tentang SISDIKNAS, Jakarta, 2006.

Departemen Agama RI, Metodologi Pendidikan Agama Islam, Jakarta: Direktorat Jendral Kelembagaan Agama Islam, 2002.

Departemen Agama RI, Al-Qur"an Al-Karim dan Terjemahnya, Cet.IV; Semarang: Karya Toha Putra Semarang, 2013.

Djaali, Psikologi Pendidikan, Cet V; Jakarta: Bumi Aksara, 2007.

Djamarah,Syaiful Bahri, Rahasia Sukses Belajar, Cet.I; Jakarta: Rineka Cipta , 2010.

Fajar, Malik, Madrasah dan Tantangan Modernitas, Bandung : Penerbit Mizan, 1998.

Gagne, Belajar dan Pembelajaran, Cet. I; Jakarta: Rineka Cipta, 1999. Hamalik,Omaer, Proses Belajar Mengajar, Cet. XI; Bandung: PT Bumi Aksara, 2010.

Hawwa,Sa"id, Tarbiyah Ruhiyah konsep Pembersihan Hati Aktivitas Dakwah, PT. Era Adicitra Intermedia, 2010.

Hasan, M. Iqbal, Pokok-Pokok Materi Statistik 1 (Statistik Deskriptif), Ed. Kedua, Cet. 1; Jakarta : Bumi Aksara, 2002.

Hasibuan dan Moedjiono, Proses Belajar Mengajar, Bandung : PT Rosda Karya, 2004.

Hasbullah, Dasar-dasar Ilmu Pendidikan, Ed. Revisi; Jakarta: PT. Raja Grafindo Persada, 2006.

Hisyam dkk, Strategi Pembelajaran Aktif, Yogyakarta : Pustaka Insani Madani, 2008.

Hilgrad dan Bower, Teori Belajar dan Pembelajaran, Cet. VII; Jogjakarta: Arruz Media, 2012.

H. TB. Aat Syafaat, dkk, Peranan Pendidikan Agama Islam dalam Mencegah Kenakalan Remaja (Juvenile Delinquency), Cet. Ed. 1-2; Jakarta: 2008.

Megawati,Reni Fita, "Penerapan Pembelajaran Operasi pada Bilangan Bulat Berbasis Teori Gagne dengan Metode diskusi Buzz Group untuk 
meningkatkan hasil belajar Siswa Kelas VII SMP Negeri 13 Jember" Skripsi, Jurusan Pendidikan Matematika Universitas Jember 2012. Online http://karya- ilmiah.uj.ac.id/index.php/mtk/article/view/14791 di akses tanggal 18 Aguatus 2016.

Munjin Nasih, Ahmad, Metode dan Teknik Pembelajaran Pendidikan Agama Islam, Bandung: PT Refika Aditama, 2009.

Muhaimin dkk, Kontoversi Pemikiran Fazlur Rahman "Studi Kritis Pembaharuan Pendidikan Islam" Cet. I : Cirebon : Pustaka Dinamika, 1999.

Mulyasa,E. Menjadi Guru Profesional, Bandung: Remaja Rosdakarya, 2008.

Musdalifa, "Studi Perbandingan Hasil Belajar Matematika sebelum dan sesudah diterapkan metode pembelajaran Buzz Group pada siswa kelas VII SMP Muhammadiyah Palopo", skripsi (Palopo: perpustakaan IAIN palopo 2014)

Purwanto,Ngalim Psikologi Pendidikan, Bandung : PT Remaja Rosdakarya, 2000.

Slameto, Belajar dan Faktor-Faktor yang Mempengaruhinya, Jakarta: Bina Aksara, 1991.

Suprijanto, Pendidikan Orang Dewasa, Jakarta : PT. Bumi Aksara, 2007.

Sudjana, Nana, Dasar-dasar Evalusi Pendidikan, Cet. II; Jakarta: Bumi Aksara, 2006.

Sriyono, Tehnik Belajar Mengajar Dalam CBSA, Jakarta: Rineka Cipta, 1992.

Sardiman, Interaksi Dan Motivasi Belajar Mengajar, Jakarta : PT Raja Grafindo Persada, 2010.

Shihab, M. Quraish, Menabur Pesan Ilahi Al-Qur"an dan Dinamika Kehidupan Masyarakat, Cet. II; Jakarta: Penerbit Lentera Ilahi, 2006.

Suprijanto, Pendidikan Orang Dewasa, Jakarta : PT. Bumi Aksara, 2007.

Suharsimi Arikunto, et.al., Penelitian Tindakan Kelas, Cet. 1; Jakarta: Sinar Grafika, 2008.

Suharsimi, et.al., Penelitian Tindakan Kelas, Cet. X; Jakarta : PT Bumi Aksara, 2011.

Surjadi, Membuat Siswa Aktif, Bandung: Bandar Maju, 1989.

Syah,Muhibbin, Psikologi Pendidikan, Cet.V; Bandung: Remaja Rosdakarya, 2000.

Trianto, Model Pembelajaran Inovatif Berorientasi Konstruktivistif, Jakarta : Prestasi Pustaka, 2007.

Trianto Ibnu Badar Al-Tabany, Mendesain Model Pembelajaran Inovatif, Progresif, dan Kontekstual, Cet. II; Jakarta: Kencana, 2015.

Usman, M Basyiruddin, Metodologi pembelajaran Agama Islam, Ciputat Pers, Jakarta, 2002. 